\title{
Construction of large dams: problems and development trends
}

\author{
Elvir Akhmetshin ${ }^{1}$, and Kseniya Kovalenko ${ }^{2}$ \\ ${ }^{1}$ Kazan Federal University, Elabuga Institute of KFU, Elabuga, Russia \\ ${ }^{2}$ Altai State University, Barnaul, Russia
}

\begin{abstract}
In this article, the authors consider the problems of using large dams, and analyze environmental and economic indicators. Reducing climate pollution and eradicating poverty are two of the most serious challenges facing the world today. More than 50,000 large dams block at least $60 \%$ of the world's rivers. The consequences of this massive engineering program are devastating. Large dams destroy species; flood vast areas of wetlands, forests, and agricultural land; moving tens of millions of people, and influencing half a billion people living downstream.
\end{abstract}

\section{Introduction}

Among the many factors leading to the degradation of river basins, dams are one of the most serious. They divide and transform aquatic ecosystems, complicate the ecological situation in the surrounding areas due to waterlogging and salinization of the area. Dams are the main reason why one fifth of the world's freshwater fish species have either disappeared or are in danger of extinction. Due to the construction of the dam, the terrestrial globe flooded a total of more than 400 thousand square meters. $\mathrm{km}$ of the most fertile land and valuable forests. Over the past half century, as a result of the construction of large dams around the world, between 40 and 80 million people have been resettled, suffering moral and material losses, the loss of their cultural values and traditions. In addition, the risks of man-made disasters as a result of the destruction of dams are quite high due to their service life.

\section{Methods}

This study uses observation methods, comparative studies, formal logic, description and interpretation, historical method. The purpose of the study is to show that the growing threats to the ecological integrity of the Earth's drainage basins come from increased population, water pollution, deforestation, excessive irrigation and public water supply, as well as flow regulation from the construction of large waterworks. Among the many factors leading to the degradation of river basin ecosystems, dams constitute one of the most

${ }^{2}$ Corresponding author: kovalenko1288@mail.ru 
important threats. They dismember and transform aquatic ecosystems, and their effects vary in duration, scale, and degree of reversibility.

\section{Results}

In 1997 in Brazil, in the city of Curitiba, the First International Conference against the construction of large dams was held, in which representatives of 20 countries of the world took part, including France, Spain, Germany, Norway, Russia, India, USA, Argentina, Brazil, Mexico and others. The forum called for governments, international agencies and investors to establish a moratorium on the construction of large dams, unless international independent expertise of projects for their construction has been carried out and the damage to people has not been compensated. and nature. It was at the Curitib Conference that it was decided to mark the day of the struggle with dams in defense of rivers, water and life on March 14 every year [1].

On the first International Day of Action against the Dams in 1998, more than 50 protests took place in 20 countries of the world, including Brazil, India, Thailand, Australia, Russia, Japan, and the USA. Tens of thousands of people took part in demonstrations, campaigns for sending letters of protest, cleaning up rivers. The following year, there were more than one hundred thousand participants.

Construction of any large reservoir is associated with significant damage to the environment, the scale of which is determined by many factors, including changes in the water regime and sediment flow, division of the basin into separate parts, flooding of land and changes in the natural conditions of the formation of aquatic and riparian ecosystems.

The construction and operation of reservoirs, especially large ones, with certain combinations of natural and anthropogenic factors often leads to a qualitative leap in speeds and characteristics of the processes of transformation of the earth's surface, the functioning of biota in aquatic, valley and upland watersheds, as well as changes in the conditions of households. Such trends in a short period can lead to changes that are catastrophic for the natural and anthropogenic landscape, affecting both the quality and the nature of people's habitat, their well-being, their standard of living, and even their spiritual world and selfexpression. And since a large dam is usually designed for a long period of operation, many negative effects can accumulate and worsen over time [2-3].

With all the diversity of impact factors, they are based, by and large, on two key processes: fragmentation / disruption of the structure of natural river systems and changes in the natural parameters of matter and energy through the river network. Since the river network is the supporting frame, the most productive part and transport system for the entire territory of the water basin, the dams and reservoirs disrupt the functioning of all subsystems in the basin - from geological to social [4]. The third most important engine of change is related human activity, induced the process of creating a reservoir and new economic conditions.

Proponents of large dams, hoping to capitalize on climate change concerns, provide the entire large expansion of large dams in developing countries. However, large dams are easily vulnerable to climate change, which changes the flow and direction of rivers, and which we cannot predict. At the same time, we need healthy rivers to adapt to climate change. We need a water and energy revolution that will reduce climate pollution and preserve the life paths of the planet. Reducing climate pollution and eradicating poverty are two of the most serious challenges facing the world today [5-9].

Hydrotechnical construction associated with the redistribution of runoff, the creation of reservoirs with huge reserves of water and considerable depth, flooding of arable land and forests, has an impact on the environment directly or indirectly. The impact on the environment affects both immediately and after many years. 
The problems, associated with the design, construction and operation of large hydraulic structures can be divided into primary, foreseen at the design stage, and secondary, arising as a result of the construction of hydraulic structures and reservoirs.

In addition, there are scientific and technical problems, both at the design and construction stages, and during the operation of reservoirs (table 1).

Table 1. The problems, associated with the design, construction and operation of large hydraulic structures

\begin{tabular}{|c|c|c|}
\hline & Primary problems & Secondary problems \\
\hline 1. & $\begin{array}{l}\text { selection of a master plan for the use of water } \\
\text { resources; }\end{array}$ & $\begin{array}{l}\text { coastal erosion of reservoirs, } \\
\text { reshaping the coast, bottom, estuarine } \\
\text { sections of rivers flowing into } \\
\text { reservoirs, the formation of bars; }\end{array}$ \\
\hline 2. & $\begin{array}{l}\text { fishery development of the reservoir, } \\
\text { construction of fish passages, restoration of the } \\
\text { natural reproduction of fish; }\end{array}$ & $\begin{array}{l}\text { danger of provocation of the earth } \\
\text { crust oscillations in connection with } \\
\text { the construction of large dams and } \\
\text { reservoirs; }\end{array}$ \\
\hline 3. & $\begin{array}{l}\text { substantiation of optimal parameters of } \\
\text { waterworks and reservoirs; }\end{array}$ & $\begin{array}{l}\text { occurrence of floating wood in the } \\
\text { reservoir waters due to coastal } \\
\text { erosion; }\end{array}$ \\
\hline 4. & $\begin{array}{l}\text { restoration of agricultural land in the new place } \\
\text { instead of flooded by the reservoir; }\end{array}$ & groundwater level changes; \\
\hline 5. & $\begin{array}{l}\text { transport development of the reservoir: an } \\
\text { increase in the depths, construction of shelters } \\
\text { for ships and rafts during storms; the creation of } \\
\text { a new ship situation, the construction of marinas; } \\
\text { transshipment of cargo through the dam; }\end{array}$ & $\begin{array}{l}\text { changes in the temperature regime of } \\
\text { the water mass and the environment, } \\
\text { increased humidity, the emergence of } \\
\text { intense and time-consuming fogs; }\end{array}$ \\
\hline 6. & $\begin{array}{l}\text { sanitary preparation of the bed before flooding } \\
\text { (disinfection of settlements, cemeteries, cattle } \\
\text { cemeteries, the elimination of various harmful } \\
\text { contaminants); }\end{array}$ & additional evaporation water loss; \\
\hline 7. & $\begin{array}{l}\text { environmental and economic rationale for } \\
\text { preparing the reservoir bed for flooding; }\end{array}$ & $\begin{array}{l}\text { changes in the qualitative composition } \\
\text { of water in the reservoir; }\end{array}$ \\
\hline 8. & $\begin{array}{l}\text { engineering protection from flooding and } \\
\text { flooding of cities, settlements, individual } \\
\text { enterprises; }\end{array}$ & violation of fish breeding grounds; \\
\hline 9. & $\begin{array}{l}\text { agroforestry meteorological hydrotechnical } \\
\text { measures to prevent water and wind erosion in } \\
\text { the zone of reservoirs; }\end{array}$ & changes in plant and animal life. \\
\hline 10. & $\begin{array}{l}\text { logging and forest clearing of the bed before } \\
\text { flooding, planting of forest plantations in a new } \\
\text { place; }\end{array}$ & \\
\hline 11. & $\begin{array}{l}\text { monitoring of water, land and forest resources in } \\
\text { the area of the hydrosystem construction. }\end{array}$ & \\
\hline
\end{tabular}

Secondary problems are more complex and interrelated, the consequences of which manifest themselves many years after the completion of construction, they are in many cases difficult to predict with sufficient scientific soundness. Many of these problems remain unsolvable in the foreseeable future.

From a financial and economic point of view, small hydrogeneration facilities have significant advantages (when adopting an appropriate package of regulatory acts), namely, short investment cycles (three to four years from the design stage) and a quick start to the company's operations and business growth. Due to the uncertainty of the forecast of tariffs 
and the growth of electricity consumption in Russia, diversification, which consists in entering the markets of renewable energy sources, which are actively developing outside of Russia, should be considered as an alternative, allowing to increase revenues and profits [10-14].

The main problem is the implementation of such projects in Siberia in difficult climatic conditions (picture 1.). With the duration of the winter period in Siberia, about seven months, small streams that are needed to generate electricity freeze, resulting in the stations becoming seasonal, that is, there is an increase in costs due to the need to use alternative sources of electricity - diesel power plants, which is not financially justified. For example, according to project documentation, the small-scale hydropower plant "Chibit" in the Republic of Altai, with an installed capacity of $24 \mathrm{MW}$, has a guaranteed capacity in December-February almost at zero level. In other words, the station in winter is practically useless in terms of generating electricity.

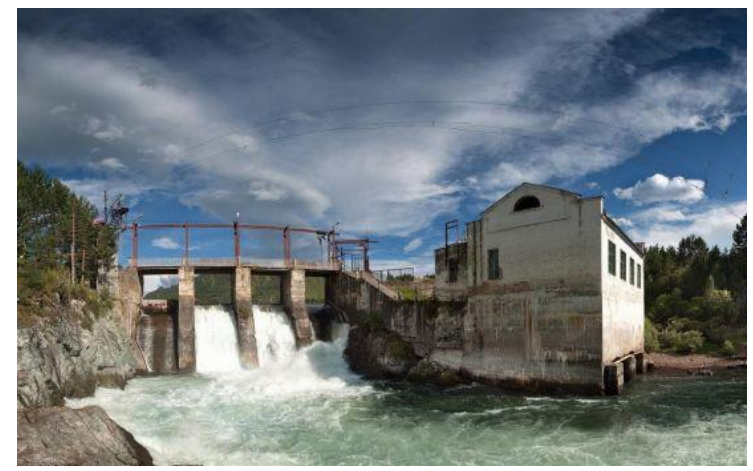

Fig. 1. Chemal hydroelectric station (Altai Territory)

Therefore, small hydrogenerations were so quickly built in the Caucasus, where the water flow in the winter practically does not freeze over, and so slowly, reluctantly they are built in Siberia [15-16]. The problem can be solved by creating a reservoir of sufficient volume, which would somehow accumulate power in the summer in order to deliver it in the winter. In Siberia, a small station will not be operated normally without a reserve of water, at least for seasonal regulation. To do this, you need to create a reservoir, which is a potential source of energy. If this is impossible to do, then talking about a small station is simply meaningless. Therefore, projects from the point of view of ecologists that are attractive from the point of view of environmentalists are hardly feasible from an economic point of view.

\section{Conclusions}

High water productivity in the global food system is definitely important. Nearly $70 \%$ of water is taken from intact ecosystems and sent to irrigate agriculture, however, rainwater irrigation - which often doubles the yield per liter of water compared to conventional irrigation methods - only $2 \%$ of the world's irrigated area.

There is a huge potential for diversity and decentralization of energy systems to meet energy needs. Energy diversification is especially important for poor states that now rely on hydropower for their electrification. Small projects spend less time on construction, are easier to enter and thus can better adapt to climate change. They are also better positioned than large centralized projects to supply energy to the many millions of villagers who need electricity. Energy efficiency is the cheapest, cleanest, and fastest solution to eliminate the energy gap in the world. Up to $3 / 4$ of electricity used in the United States could be saved 
with an efficiency measured by a price less than electricity itself. Developing countries, which are responsible for $80 \%$ of the growth in energy consumption until 2020, could cut this growth by more than half using existing efficient technologies.

Even with investments in efficiency, however, many developing countries will require new sources of power generation. Developing countries often have significant, unused potential of renewable energy sources, such as solar, wind, geothermal, as well as the possibilities of modern biomass energy, dam-free hydroelectric power plants with low climate impact. Such technologies are much more in line with energy needs in poor rural areas, they can also develop where people need electricity, and there is no need to build power lines.

\section{References}

1. Z. Liu, S.P. Meng and H. Zang, et al. Journal of Southeast University (Natural Science), 37 (2), 291-295 (2007)

2. D.S. Griffin and R.S. Varga. Journal of the Society for Industrial \& Applied Mathematics, 11 (4), 1046-1062. (1963)

3. B.I. Kochurov. Geography of ecological situations (eco-diagnostics of territories). (Moscow, IG RAS, 2014)

4. J. Shen, S. Lassue and L. Zalewski, et al. J. Energy \& Buildings, 39 (8), 962-974 (2007)

5. H. Ali, N. Ali, A. R.Ahmad, M.Ibrahim, S.Ahmad, S. Yaacob. Advances in natural and applied sciences, 6 (2017)

6. J. Cleary. Environment international, 35 (2018)

7. L. A. Nagashima, Junior C. Barros, C. C.Andrade, E. T. Silva, C. Hoshika. Gestão integrada de resíduos sólidos urbanos - uma proposta para o município de Paranavaí, Estado do Paraná, Brasil. Acta Scientiarum. Technology, Maringá, 33 (2015)

8. M. C. E. Lloréns, M. L. T. Torres, A. P. A. Arrechea, R. M. Navarro, A. F. Colomina. La fracción orgánica de los residuos sólidos urbanos como fuente potencial de producción de biogás. Revista CENIC Ciencias Biológicas, 38 (2017).

9. P. Sarkhel, S.Banerjee. Environment, Development and Sustainability, 12 (2017)

10. R. A. Begum, C. Siwar, J. J. Pereira, A. H. Jaafar. Waste Management, 27 (2017)

11. S. E. Shmelev \& J. R. Powel,. Ecological-economic modelling for strategic regional waste management systems. Ecological Economics, 59 (2016)

12. T. Eshet, O.Ayalon \& M. Shechter. Resources, Conservation and Recycling, 46 (2016)

13. V. F. Nascimento, A. C. Sobral, P. R. Andrade. Evolução e desafios no gerenciamento dos resíduos sólidos urbanos no Brasil. Rev. Ambient. Água, Taubaté, 10 (2018)

14. V. Owusu, J. M. Boaherg, C. Sundberg. Journal of Environmental Studies and Sciences, 1 (2015)

15. H. Emoto, J.Takahashi, et.al. A. Procedia Engineering, 95, 65-74 (2014)

16. S. Sasmal, K., Ramanjaneyulu, et.al. N. Americal Society of Civil Engineers, 261-273 (2006) 